\title{
Grooming behavior and damaged mites (Varroa jacobsoni) in Apis cerana cerana and Apis mellifera ligustica
}

\author{
I Fries ${ }^{1}$, Wei Huazhen 2, Shi Wei 2, Chen Shu Jin ${ }^{2}$ \\ 1 Department of Entomology, Swedish University of Agricultural Sciences, \\ S-75007 Uppsala, Sweden; \\ 2 Institute of Apicultural Research, Chinese Academy of Agricultural Sciences, \\ Xiang Shan, Beijing 100093, China
}

(Received 15 August 1995; accepted 23 November 1995)

\begin{abstract}
Summary - Varroa mite mortality and mite damage in colonies of Apis cerana cerana Fabr and Apis mellifera ligustica Spin, where mites were added to observation hive bees and to full-sized colonies of both bee species, were studied. The results show grooming behavior in $A$ cerana but the results also indicate that this behavior may be less effective than previously recorded. In $A$ mellifera colonies, phoretic mites were also removed by the bees but less effectively than in $A$ cerana colonies. The proportion of experimentally-added live mites in the debris that were visibly damaged in colonies of $A$ cerana was $30 \%(n=115)$. From A mellifera colonies, $12.5 \%$ of the introduced mites had visible injuries caused by the bees $(n=65)$. The mites recovered from both bee species showed reduced survival rate on bee pupae compared to control mites. Compared to $A$ mellifera, $A$ cerana is more effective in both removing mites and causing mite damage. However, in $A$ mellifera phoretic mites are also removed by the bees, and some of them are injured. Since no reproduction of Varroa mites occurs in worker brood in A cerana, extremely effective grooming behavior may not be needed to explain the folerance of $A$ cerana to Varroa mite infestations. The results presented demonstrate that more research is needed to evaluate the importance of grooming behavior to Varroa mite tolerance in both A cerana and $A$ mellifera.
\end{abstract}

Apis mellifera / Apis cerana / grooming behavior / Varroa jacobsoni / tolerance

\section{INTRODUCTION}

The parasitic mite Varroa jacobsoni attacks both the European honey bee (Apis mellifera) and the Asian honey bee (Apis cerana). A cerana is the original host of the parasite (Koeniger et al, 1981), while the
Varroa mite has become widely distributed in $A$ mellifera comparatively recently. $\ln A$ cerana there is a balanced host/parasite relationship in the sense that the mite does not seriously damage or kill the host. Varroatolerant populations of $A$ mellifera are found in South America in hybrids between Euro- 
pean and African bees (Camazine, 1986; Engels et al, 1986; Ritter and De Jong, 1984) and in A mellifera populations in Tunisia (Ritter, 1990). However, in most cases $A$ mellifera colonies die if the mite population is not controlled.

The mechanisms behind the tolerance of $A$ cerana to Varroa mite infestations were investigated by Peng et al (1987). They found extensive grooming behavior in $A$ cerana that resulted in removal of more than $99 \%$ of mites added to colonies in observation hives $(n=270)$. Only $0.3 \%$ of the mites were removed by grooming in colonies of $A$ mellifera $(n=270)$. Of 42 mites examined from the hive bottom of $A$ cerana, $73.8 \%$ had visible injuries although no mites from $A$ mellifera were examined. Büchler et al (1992) also compared grooming in $A$ cerana and $A$ mellifera and found successful mite removal in $75 \%$ of the cases in $A$ cerana $(n=36)$. In $A$ mellifera, $48 \%$ of the mites were removed by grooming $(n=25)$. Effective removal of Varroa mites has also been reported from colonies of $A$ cerana japonica (Takeuchi, 1993).

Damaged mites can be found on the bottom board in all Varroa-infested $A$ mellifera colonies, and injuries on Varroa mites, probably caused by grooming, have been observed in A mellifera (Ruttner and Hänel, 1992) in Europe. Moosbeckhofer (1992) found a significant negative correlation between the proportion of damaged mites and the population size of the Varroa mite in infested colonies. This indicates that grooming behavior expressed as a proportion of damaged mites may be a useful parameter in selecting for Varroa tolerance.

The extent and variation of mite damage in some $A$ mellifera populations is well documented (Moosbeckhofer, 1992; Wallner, 1994). There is, however, no information about the level of mite damage from colonies of $A$ cerana naturally infested by the Varroa mite. This paper reports on observations of mite damage from obser- vation hive experiments and full sized colony experiments using both $A$ cerana and $A$ mellifera colonies. We also report on mite damage in naturally infested colonies of both bee species.

\section{MATERIAL AND METHODS}

The experiments presented were performed near Beijing during August and September 1994. The bees used were a Chinese strain of $A$ mellifera ligustica and colonies of $A$ cerana cerana from the mountain area $120 \mathrm{~km}$ south of Beijing.

All mites used in the presented experiments were phoretic mites collected from one heavily infested $A$ mellifera colony. Infested bees were shaken into a box with one side covered by a net, allowing mites to fall through the net. The bees were shaken in the box with the net side up after adding a small amount of wheat flour. Thereafter the box was turned with the net side down and the mites falling from the bees were collected in a container. In the laboratory each mite was transferred and cleaned, if needed, onto a semi-damp piece of cloth and allowed to walk for approximately half an hour. After that the mites were used for inoculation experiments. The mites were inoculated on bees or pupae within an hour of collection.

\section{Observation hive experiments}

Two colonies of $A$ cerana and one colony of $A$ mellifera were used. The addition of mites onto marked bees followed the procedures described by Peng et al (1987) and the observation hives used were the same as used by these authors. Ten to forty mites were added each time to each colony.

Observations were made of the behavior of individual bees and of mites falling from the bees to the bottom of the hive. At the hive bottom there was a white sheet of paper from which the mites could be collected after falling. Each fallen mite was examined under a stereo microscope at 63fold magnification for visible signs of damage. One hour after inoculating the mites onto each tagged bee, the individual bees were examined for the presence or absence of mites. 
The experiment was repeated twice in one $A$ cerana colony, inoculating ten mites each time. This colony had one comb and contained approximately 800 bees. In another A cerana colony the experiment was conducted once, inoculating 40 mites. This colony had three combs and contained approximately 4500 bees. In the $A$ mellifera observation hive (two combs, approximately 3500 bees) the experiment was repeated twice, with ten and twenty mites respectively.

\section{Full-sized colonies}

Three $A$ cerana colonies and three $A$ mellifera colonies in Langstroth standard hives were equipped with net bottoms to allow collection of mites under the colonies. The colonies were monitored daily for mite mortality for one month, and all mites from the A cerana and some of the mites from the $A$ mellifera colonies were examined for mite damage. In the $A$ cerana colonies the bees covered four, five and six combs respectively and in the $A$ mellifera colonies the corresponding numbers were 10, 12 and 15 combs. All six experimental colonies were put on stands approximately $50 \mathrm{~cm}$ from the ground with the legs of the stands in water containers, to avoid ants or other animals gaining access to the hive debris.

At the end of the collection period, two colonies from each bee species were used to investigate mites falling from the colonies after introduction of mites directly upon the bees on top of or in between the frames. Forty eight hours after adding mites, possible residual mites were regarded as an integrated part of the colony and the colony was used for further experiments.

Sixty mites were added into each of two $A$ cerana colonies and the experiment was repeated again in one of these hives using 100 mites. In two A mellifera colonies 40 mites were added to each hive and the experiment was repeated again in both hives using 100 mites in each hive. Mites were collected from under the colonies 15 and $30 \mathrm{~min}, 1,2,3,4,5$ and $6 \mathrm{~h}$ after the time of introduction. Each mite which fell during the collection period was examined under a stereo microscope for signs of damage.

A number of fallen mites from each colony where no visible damage could be seen under the microscope were incubated at $+34^{\circ} \mathrm{C}$ on redeyed pupae from $A$ mellifera. At the same time control mites, collected together with the mites added to the colonies, were incubated in the same way. The survival success of the mites was measured three times at $24 \mathrm{~h}$ intervals. The numbers of incubated mites were 26 for $A$ cerana, 41 for $A$ mellifera and 40 control mites.

\section{RESULTS}

\section{Observation hive experiments}

In the first $A$ cerana colony only six of the 20 mites added were recovered. Five of these mites were found on the bottom of the hive and examined for damage; none had any visible damage. One mite was found on the bee onto which it had been added. In the second $A$ cerana colony 11 of 40 mites added were recovered on the bottom board. Two of the recovered mites had visible damage probably caused by the bees. No mite was found on the tagged bee onto which it had been introduced.

In the A cerana colonies we observed most of the marked bees (55 out of 60 ) instantly performing auto-grooming ('selfcleaning') after placing the mite on the bee's body. The remaining bees all performed grooming or appeared disturbed by the presence of the mite but this behavior was observed several minutes later and may be indistinct. After a few minutes some of the bees were involved in allo-grooming ("nestmate cleaning') as described by Peng et al (1987). However, we also clearly observed, at least on three occasions, a mite leaving a marked bee and moving onto another bee. Separate observations were also made where mites could be seen on bees other than the original mite-receiving bees. It should be noted that it is very difficult to register with certainty the destiny of mites placed on individual bees. They may move to parts of the bee where they cannot be observed, or move onto other bees undetected. With the system used, however, the mites removed from the bees were likely to 
be found on the bottom of the hive since the flight activity was low.

In the $A$ mellifera colony, mites were added on two occasions making a total of 30 mites. Only 6 of these mites were recovered from the bottom of the hive and examined. None of these had been visibly damaged. Only one mite was found on the bee onto which it was added.

A direct reaction of $A$ mellifera to adding the mite onto the bee's body was absent in many cases (17 out of 30 ). Some cases that could be interpreted as auto-grooming or disturbed behavior were observed (13 out of 30) but not the intense grooming dance performed by many $A$ cerana bees. No clear cases of allo-grooming were observed in $A$ mellifera.
The results from the observation hives are summarized in table $\mathrm{I}$.

\section{Full-sized colonies}

During one month, only four mites were recovered from the bottom of the A cerana colonies. From one colony no mites were recovered. From the second colony one mite was recovered, and in the third three mites were found. None of these mites had visible injuries (table II).

In the three A mellifera colonies, a total of 258 mites falling naturally from the colonies were collected in 24 hour intervals (table II). Of these mites $26.4 \%$ had detectable injuries. Of the 258 collected mites, 132

Table I. Total numbers of mites introduced, recovered on the bottom within $1 \mathrm{~h}$, and damaged in observation hives of Apis cerana and Apis mellifera.

\begin{tabular}{lcccc} 
Species & $\begin{array}{c}\text { Number of } \\
\text { introduced mites }\end{array}$ & $\begin{array}{c}\text { Number of } \\
\text { recovered mites }\end{array}$ & $\begin{array}{c}\text { Number of } \\
\text { damaged mites }\end{array}$ & $\begin{array}{c}\text { Percentage of } \\
\text { damaged mites (\%) }\end{array}$ \\
\hline Apis cerana & 60 & 16 & 2 & 12.5 \\
Apis mellifera & 30 & 6 & 0 & 0
\end{tabular}

Table Il. Total numbers of mites introduced, recovered on the bottom within $6 \mathrm{~h}$, and damaged in fullsized colonies of Apis cerana and Apis mellifera; also given is the number of dead mites investigated from a natural mite population.

\begin{tabular}{lcccc} 
Species & $\begin{array}{c}\text { Number of } \\
\text { introduced mites }\end{array}$ & $\begin{array}{c}\text { Number of } \\
\text { recovered mites }\end{array}$ & $\begin{array}{c}\text { Number of } \\
\text { damaged mites }\end{array}$ & $\begin{array}{c}\text { Percentage of } \\
\text { damaged mites (\%) }\end{array}$ \\
\hdashline..- & 220 & $115^{\mathrm{a}}$ & 34 & $29.6^{\mathrm{a}}$ \\
Apis cerana & 280 & $65^{\mathrm{b}}$ & 8 & $12.3^{\mathrm{b}}$ \\
Apis mellifera & 28 & 0 & 0 \\
Apis cerana & Natural & 258 & 68 & 26.4 \\
Apis mellifera & Natural & & & \\
- & & &
\end{tabular}


Fig 1. Cumulative percent (\%) of all inoculated mites $(n=240$ for $A$ cerana, $n=280$ for $A$ mellifera), recovered on the bottom board.

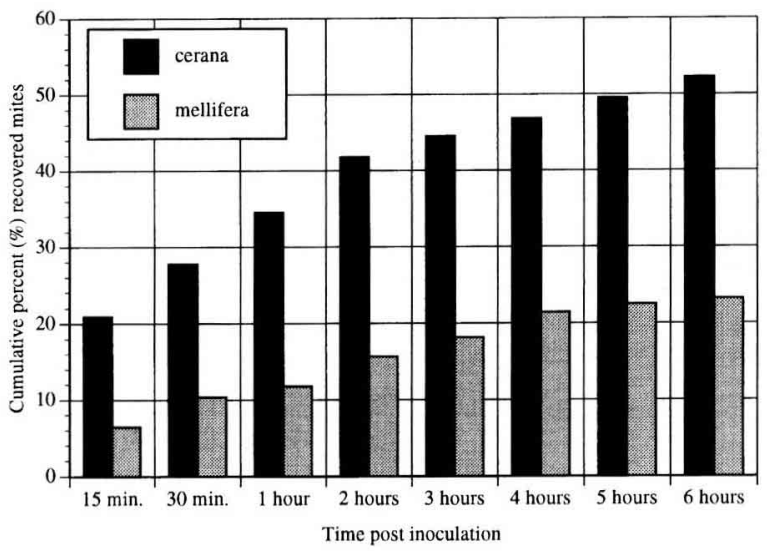

were alive when they were collected. Only $9.1 \%$ of the live mites had detectable injuries.

During the $24 \mathrm{~h}$ preceding the first experiments with adding mites, the two $A$ mellifera colonies used had natural mite mortalities of zero and two mites respectively. When the experiment was repeated, the natural mite mortalities during the $24 \mathrm{~h}$ before the experiment were four mites in each of the two colonies used.

Figure 1 presents the cumulative percentage recovery of all mites added during $6 \mathrm{~h}$ for the A cerana and $A$ mellifera colonies. Of the 115 mites recovered within $6 \mathrm{~h}$ in the A cerana colonies, 34 mites $(29.6 \%)$ had visible signs of damage caused by the bees. Often one or more legs per mite were missing, but cases where only the pretarsus of one leg was missing were also recorded. The proportion of mites recovered from $A$ mellifera colonies within $6 \mathrm{~h}$ was significantly lower than from the $A$ cerana colonies $\left(P<0.001, \chi^{2}=45.2,1 \mathrm{df}\right)$. Of the 65 mites recovered, eight had been visibly damaged by the bees $(12.3 \%)$. Thus, the proportion of damaged mites in the $A$ mellifera colonies was significantly lower than in the $A$ cerana colonies $\left(P<0.05, \chi^{2}\right.$ $=6.9,1 \mathrm{df}$ ). A total of three mites fallen from the $A$ mellifera colonies were not considered in the calculations since their appear- ance (dead, light colored) indicated that they were not mites added to the colonies. The low natural mite mortality in the experimental colonies may slightly influence the calculations but not the conclusions. The data on mites collected from full-sized colonies are summarized in table II.

In figure 2 the survival success of mites fallen from the bees and then incubated on pupae is presented. The mite mortality at 24 $h$ post incubation was already significantly higher than for the control mites incubated one hour after collection from the adult bees, both for $A$ cerana $\left(P<0.05, \chi^{2}=4.72,1 \mathrm{df}\right)$ and $A$ mellifera $\left(P<0.05, \chi^{2}=4.91,1 \mathrm{df}\right)$. At 48 and $72 \mathrm{~h}$ post incubation the mortality of the mites from $A$ cerana was significantly higher than for those collected from $A$ mellifera colonies $\left(P<0.05, \chi^{2}=5.5,1 \mathrm{df}\right.$ and $P$ $<0.05, \chi^{2}=4.4,1 \mathrm{df}$ respectively).

\section{DISCUSSION}

A substantial proportion of mites are damaged by bees in $A$ mellifera colonies. In this investigation, $26.4 \%$ of all the naturally fallen mites had injuries while only $9.1 \%$ of fallen live mites had injuries. This could indicate either that mites die when they become injured, or that the bees injure already dead or non-vital mites. $A$ mellifera do injure 


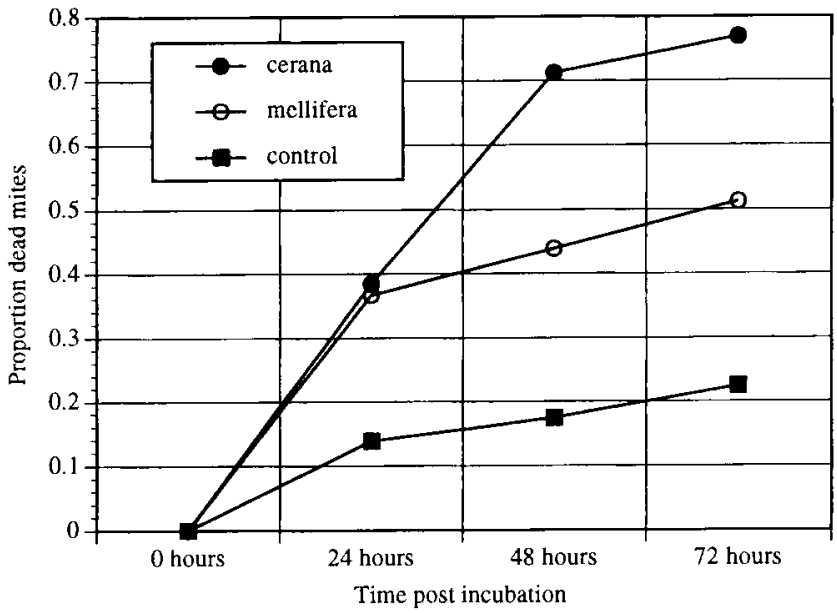

Fig 2. Survival rate of Varroa mites fallen from colonies of $A$ cerana $(n=26)$ and $A$ mellifera $(n=41)$ and incubated on bee pupae compared to incubated control mites $(n=39)$. already dead Varroa mites introduced with hatching brood into colonies (Rosenkranz et al, in preparation).

Although not evident from the observation hive experiments, the presented results demonstrate that $A$ cerana is more efficient in both removing and damaging live vigorous Varroa mites compared to A mellifera. This is congruent with earlier studies where grooming behavior has been considered (Büchler et al, 1992; Peng et al, 1987; Takeuchi, 1993). However, the damage caused to the mite population by the grooming behavior reported here is substantially different from some earlier reports (Peng et al, 1987). The proportion of mites removed from the bees in this investigation is lower in $A$ cerana and higher in $A$ mellifera than reported by Peng et al (1987). The proportion of damaged mites is also lower in $A$ cerana than previously reported. It should be pointed out, though, that the observations of removed mites only refer to mites found on the bottom. In the observation hives removal of mites from the hives was probably limited due to low flight activities. In the full-sized colonies, however, the possibility cannot be excluded that some of the introduced mites were thrown out from the colonies and that this behavior may vary between bee species. Thus, the results presented here should be interpreted with great caution and, rather than demonstrating a specific grooming efficacy in the tested bees, they indicate that more research is needed. It should also be noted that in this experiment most of the mites dropped from the colonies within the first few hours after introduction. This may not reflect natural conditions and it should be emphasized that there is a need to study to what extent mites are damaged in $A$ cerana colonies under natural conditions. The few mites collected from the debris in naturally infested $A$ cerana colonies in this investigation $(n=4)$ had no visible damage.

For both bee species in this investigation, some mites that fell from the bees, where no visible physical damage could be detected, still seemed to be damaged by the bees. The survival rate of control mites incubated on pupae was significantly higher than that of the mites fallen from $A$ cerana or A mellifera colonies. This effect could depend in part on dehydration or other experimental effects on the fallen mites but the difference demonstrated between bee species clearly indicate an effect from the bees. Thus, to evaluate the impact of honey bee behavior on the survival of the mites, 
it is not sufficient to consider only visibly damaged mites.

There may be several explanations for the described discrepancies to earlier observations. Peng et al (1987), who only worked with observation hives, considered movement of mites from one bee to another as successful mite removal. From the point of view of mite tolerance of the colony, mites need to be removed not only from individual bees but from the colony. Thus, in this investigation we did not consider change of host to be successful removal of mites. The mites we registered as having been removed by the bees were collected from under the bees in all cases (observation hive experiments and colony experiments). In our observation hive experiments we were not able to see when the mites changed their host in many cases.

Another possible explanation for the noted differences to earlier studies may be the source of bees. Peng et al (1987) used A cerana from the south of China, while the A cerana bees in this investigation came from the Beijing area. The source of mites could also influence the results. We used only mites collected from adult bees, while Peng et al (1987) used both phoretic mites and mites collected from a sealed brood.

The full-sized colony experiments demonstrate that the studied $A$ cerana colonies were much more effective in injuring and removing mites from the adult bees than the $A$ mellifera colonies. However, in this study this behavior is also present in $A$ mellifera to a substantial degree. The source of mites ( $A$ mellifera) may enhance the grooming effect in A cerana since odor is an important cue for detecting mites (Rosenkranz et al, 1993). There is a need to study a much larger number of colonies with respect to grooming behavior before any conclusions should be made concerning its relative importance for Varroa mite tolerance in $A$ cerana or $A$ mellifera. The relative importance of this behavior for Varroa mite tolerance is not demonstrated in this or any other investigation and the grooming behavior alone probably cannot explain mite tolerance in A cerana (Boecking et al, 1993). In simulations of the population growth of the Varroa mite in colonies of $A$ mellifera, the relative importance of reproduction in the worker brood is obvious (Fries et al, 1994). These simulation studies indicate that, if there is no reproduction in the worker brood, the need for effective grooming to keep the mite population under control may be reduced. Understanding the relative importance of various factors that contribute to the Varroa mite tolerance in $A$ cerana, or in other mite-tolerant honey bees, may be important for evaluating available options in $A$ mellifera. In the search for a possible solution to the Varroa mite problem through breeding in colonies of $A$ mellifera, the host-parasite relationship in the original host of the mite needs to be studied further.

\section{ACKNOWLEDGMENT}

This study was supported by the Swedish Council for Forestry and Agricultural Research.

Résumé - Étude comparative du comportement de toilettage et du nombre d'acariens lésés (Varroa jacobsoni) chez Apis cerana cerana et Apis mellifera ligustica. On a étudié la mortalité de l'acarien Varroa jacobsoni et ses lésions (principalement la perte ou les lésions d'une ou plusieurs pattes) dans des ruches d'observation, auxquelles des varroas avaient été ajoutés, et dans des colonies entières des deux espèces Apis cerana cerana et Apis mellifera ligustica. Dans les ruches d'observation, des varroas prélevés dans des colonies d'A mellifera ont été introduits sur des abeilles marquées, selon le protocole de Peng et al (1987). Trente varroas ont été ajoutés aux colonies d'A mellifera et 60 à 
celles d'A cerana. Les varroas éliminés par les abeilles et tombés sur le plancher de la ruche dans l'heure suivant l'introduction ont été récoltés et leurs lésions étudiées. La présence de varroas sur les abeilles marquées a été recherchée une heure après leur introduction. Dans les colonies entières, les varroas, prélevés dans des colonies de mellifera, ont été introduits directement audessus des abeilles sur les barettes supérieures (en tout 280 dans les colonies de mellifera et 220 dans celles de cerana). Les varroas tombés des abeilles ont été récoltés sous les fonds grillagés des ruches 15 minutes, 30 minutes, 1, 2, 3, 4, 5 et 6 heures après leur introduction. Leurs lésions ont été étudiées. Les résultats montrent l'existence chez A cerana d'un comportement de toilettage, mais il n'est pas aussi efficace que précédemment décrit. Dans les ruches d'observation d'A cerana, le comportement de toilettage décrit par Peng et al (1987) a été observé, mais il est clair également que certains varroas changent simplement d'hôte lorsque que survient le toilettage. D'après les observations, $27 \%$ seulement des varroas introduits (16 sur 60 ) ont été éliminés par les abeilles en 1 heure. Sur les varroas éliminés, seuls deux $(12,5 \%)$ ont été visiblement lésés par les abeilles. Sur les 30 varroas introduits sur les abeilles $A$ mellifera, six ont été éliminés par elles et retrouvés sur le plancher $(20 \%)$. Aucun d'entre eux ne présentaient de lésion. Dans les colonies entières d'A mellifera, les varroas ont également été éliminés par les abeilles mais de façon bien moins efficace que dans les colonies d'A cerana. La proportion de varroas vivants retrouvés dans les débris dans les 6 heures suivant l'introduction et présentant visiblement des lésions a été de $30 \%(n=115)$ dans les colonies d'A cerana et de $12 \%(n=65)$ dans les colonies d'A mellifera. Comparée à $A$ mellifera, $A$ cerana est plus efficace pour se débarrasser des acariens et leur causer des lésions. Néanmoins, ces deux comportements sont également présents chez $A$ mel- lifera. Puisque $V$ jacobsoni ne se reproduit pas dans le couvain d'ouvrières d'A cerana, la grande efficacité du comportement de toilettage mentionnée auparavant n'est peutêtre pas nécessaire pour expliquer la tolérance d'A cerana aux infestations par $V$ jacobsoni. Nos résultats montrent que des recherches complémentaires sont nécessaires pour comprendre l'importance du comportement de toilettage dans la tolérance à Varroa, aussi bien chez $A$ cerana que chez A mellifera.

Apis mellifera / Apis cerana / comportement toilettage / Varroa jacobsoni/sensibilité résistance

\section{Zusammenfassung - Putzverhalten und beschädigte Milben (Varroa jacobsoni) bei Apis cerana cerana und Apis melli-} fera ligustica . Mortalität und Verletzungen (meist ein oder mehrere Biene verletzt oder fehlend) von Varroa wurden an Völkern von Apis cerana cerana und Apis mellifera ligustica untersucht. Hierzu wurden die untersuchte Milben zu normalen Bienenvölkern und zu Beobachtungsstöcken zugesetzt. In den mit $A$ mellifera und $A$ cerana besetzten Beobachtungsstöcken wurden phoretische Milben aus Völkern von A mellifera entsprechend den Methoden von Peng et al (1987) auf gekennzeichnete Bienenarbeiterinnen aufgebracht. Bei $A$ mellifera wurden 30, bei $A$ cerana 60 Milben zugesetzt. Die innerhalb der folgenden Stunde von den Bienen entfernten Milben wurden vom Beutenboden aufgesammelt und auf Verletzungen untersucht. Die gekennzeichneten Bienen wurden nach dieser Stunde auf Milbenbefall untersucht. In den normalen Bienenvölkern beider Bienenarten wurden die ebenfalls von $A$ mellifera abgesammelten Milben direkt auf die auf den Oberträgern der Waben sitzenden Arbeiterinnen aufgesetzt. Die herunterfallenden Milben wurden 0,25, $0,5,1,2,3,4$ und 6 Stunden nach Einsetzen der Milben unterhalb eines Drahtgitters im 
Beutenboden eingesammelt. Alle diese Milben wurden auf Beschädigungen untersucht. Insgesamt wurden 280 Milben in Völker von A mellifera und 220 in Völker von A cerana eingesetzt. Die Ergebnisse zeigen zwar einen deutlichen Effekt des Putzverhaltens bei $A$ cerana, allerdings deuten sie darauf hin, daß dieser wesentlich geringer ist als früher berichtet. Das von Peng et al (1987) beschriebene Putzverhaltens konnte zwar ebenfalls beobachtet werden, es war aber deutlich, daß ein Teil der Milben daraufhin lediglich auf eine andere Wirtsbiene wechselte. Nur von $27 \%$ der eingesetzten Milben (16 von 60 ) konnte beobachtet werden, daß sie innerhalb einer Stunde von den Bienen entfernt wurden. Von diesen zeigten nur 2 $(12,5 \%)$ sichtbare Beschädigungen durch die Bienen. Von den 30 auf Arbeiterinnen von $A$ mellifera aufgebrachten Milben wurden $6(20 \%)$ von diesen entfernt und auf dem Beutenboden wiedergefunden. Keine dieser Milben war sichtbar verletzt. Auch in normal großen Völkern wurden aufsitzende Milben von $A$ mellifera-Arbeiterinnen entfernt, allerdings weniger effektiv als von $A$ ceranaArbeiterinnen. Bei $A$ cerana betrug der Anteil verletzter Milben an den innerhalb von 6 Stunden auf dem Beutenboden wiedergefundenen Milben 30\% $(\mathrm{N}=115)$, bei $A$ mellifera $12 \%(\mathrm{~N}=65)$. A cerana kann damit wirkungsvoller als $A$ mellifera die Milben entfernen und innen Verletzungen beibringen. Allerdings ist auch $A$ mellifera hierzu in der Lage. Da Varroa sich in den Arbeiterinnenbrutzellen von $A$ cerana nicht vermehrt, ist die Toleranz von $A$ cerana gegenüber einem Befall durch Varroa auch ohne ein so hocheffektives Putzverhalten, wie dies früher berichtet worden war, erklärlich. Die vorliegenden Ergebnisse zeigen, daß zur Abschätzung der tatsächlichen Bedeutung des Putzverhaltens für die Toleranz sowohl von $A$ mellifera als auch von $A$ cerana weitere Untersuchungen erforderlich sind.

\section{Varroa jacobsoni / Apis mellifera / Apis cerana / Putzverhalten / Toleranz}

\section{REFERENCES}

Boecking O, Rath W, Drescher W (1993) Grooming and removal behavior - strategies of Apis mellifera and Apis cerana against Varroa jacobsoni. Am Bee $J$ 133, 117-119

Büchler R, Drescher W, Tornier I (1992) Grooming behaviour of Apis cerana, Apis mellifera and Apis dorsata and its effect on the parasitic mites Varroa jacobsoni and Tropilaelaps clareae. Exp Appl Acarol $16,313-319$

Camazine S (1986) Differential reproduction of the mite Varroa jacobsoni (Mesostigmata, Varroidae), on Africanized and European honey bees (Hymenoptera, Apidae). Ann Entomol Soc Am 79, 801-803

Engels W, Goncalves LS, Steiner J, Buriolla AH, Cavichio Issa MR (1986) Varroa-Befall von Carnica-Völkern in Tropenklima. Apidologie 17, 203-216

Fries I, Camazine S, Sneyd J (1994) Population dynamics of Varroa jacobsoni: a model and a review. Bee World 75, 5-28

Koeniger N, Koeniger G, Wijayagunasekara NHP (1981) Beobachtungen über die Anpassung von Varroa jacobsoni an ihren natürlichen Wirt Apis cerana in Sri Lanka. Apidologie 12, 37-40

Moosbeckhoter R (1992) Beobachtungen zum Auftreten beschädigter Varroamilben im natürlichen Totenfall bei Völkern von Apis mellifera carnica. Apidologie 23, 523-531

Peng YS, Fang $Y, X u S$, Ge $L$ (1987) The resistance mechanism of the Asian honey bee Apis cerana Fabr. to an ectoparasitic mit, Varroa jacobsoni Oudemans. J Invertebr Pathol 49, 54-60

Ritter W (1990) Entwicklung der Varroamilbenpopulation in behandelten und unbehandelten Völkern in Tunesien. Apidologie 21, 368-370

Ritter W. De Jong D (1984) Reproduction of Varroa jacobsoni Oud in Europe, the Middle East and tropical South America. Z Angew Entomol 98, 55-57

Rosenkranz P, Tewarson NC, Singh A, Engels W (1993) Differential hygienic behaviour towards Varroa jacobsoni in capped worker brood of Apis cerana depends on alien scent adhering to the mites. J Apic Res 32 , 89-93

Ruttner F, Hänel H (1992) Active defense against Varroa mites in a Carniolan strain of honeybee (Apis mellifera carnica Pollmann). Apidologie 23, 173187

Takeuchi K (1993) Extinction of Varroa mites in Japanese honeybee (Apis cerana japonica) Rad colony. Honeybee Sci 14, 58-60 (in Japanese)

Wallner A (1994) Der Varroakillerfaktor. Dtsch Bienen J 2, 372-374 